\title{
SERVICE QUALITY OF GOODS AND SERVICES PROCUREMENT UNITS TOWARDS CUSTOMER'S SATISFACTION
}

\author{
Bayu Indra Setia \\ bayu_indrasetia@unpas.ac.id \\ Atty Tri Juniarti \\ Rohmat Sarman \\ Erry S.R. Pangestu \\ Universitas Pasundan \\ J1. Tamansari No.6-8, Bandung 40116
}

received: 5/6/20; revised: 18/6/20; approved: 29/6/20

\begin{abstract}
Subang District has become surprisingly attractive by the existence of Patimban Port. The presence of investor has given impacts to the number of studies and works requiring the performance of Procurement Service Units (trans. Unit Layanan Pengadaan - ULP) of goods and services that satisfy customers, namely the Regional Work Unit (trans. Satuan Kerja Perangkat Daerah - SKPD) and Partners. Method used are descriptive and verifiative by using path analysis. The service quality is measured with the dimensions of tangible, empathy, responsiveness, reliability, and assurance. The descriptive result showed that service quality and customers'satisfaction were pretty good and dimension of responsiveness had smallest average score as well. Meanwhile, the verificative result showed that there were positive and significant effects, both simultaneously and partially, on the dimension of empathy, responsiveness, reliability, and assurance towards customers'satisfaction.
\end{abstract}

Keywords: service quality; procurement service units; regional work unit; customers 'satisfaction; subang district

\section{INTRODUCTION}

Procurement unit has one of the most important functions in government organization, but it still does not have an adequate attention. The current procurement function is still mostly handled on an ad-hoc basis by committees that are formed and work temporarily (not permanently). Such systems have many weaknesses and will also lead to a low procurement performance of goods/ services in the central/regional government institutuion. Its low performance will adversely affect to the performance of government organizations as well, including public service provided to the society (Lembaga Kebijakan Pengadaan Barang/Jasa Pemerintah, 2013).

In fact, both in central and regional government, these indications are easily to find in carrying out the tasks of procurement committee. These are weaknesses of ad-hoc procurement organization, there are (1) mostly vulnerable to the influence in term of personal interest and interventions; (2) various kind of skills and competencies of procurement executives; (3) professionalism is not guaranteed and measurable; (4) lack of focus in implementation, because the executives still currently hold another postitions/ activities; (5) the number of expertise, experience and skills are mostly ineffective; (6) no guarantee of career development in the field of PBJP; (7) management of record, documentation and information cannot be carried out properly (Lembaga Kebijakan Pengadaan Barang/ Jasa Pemerintah, 2013).

The condition gives effects to a vulnerable occurrence of procedural irregularities and authority abuse in the implementation of procuring goods/ services which also sometimes ends up in corruption. Quantitatively, the number of corruption cases in the field of goods/service procurement is relatively high every year, both from the cases that have occurred and the amount of state financial losses; 70 percent of them are from the procurement field. In term of quality, the corruption committed also systematically increases and covers all aspects of public life, both in Central, Regional, Legislative and Private government involved in the procurement of goods/services. (Head of Sub-Directorate of Criminal Acts and Investigation, Police Headquarters, Senior Commissioner, Akhmad Wiyagus at Kadin Tower, Jakarta, Monday, September 24th, 2012, www.tempo.com). 
In connection with the efforts of bureaucratic reform in the field of procurement of government goods and services, among three aspects becoming the scope of bureaucratice reform, the institutional aspects of procurement services are still a major obstacle. In the area of management, the government has already simplified various procedures for procuring goods/ services to be more accountable and transparent by implemementing the system of e-procurement and e-purchasing, as well as improving procurement regulations and procedures. The field of Human Resources has already been standardized by increasing personnel competency through the program of profession certification of government goods/services procurement, as well as determining functional position of goods/ services procurement manager (Peraturan Menteri Pendayagunaan Aparatur Negara dan Reformasi Birokrasi Nomor 77 Tahun 2012).

These institutional issues related to the procurement were overcome by Peraturan Presiden Nomor 54 Tahun 2010 concerning of Procurement Government Goods/ Services (last amended by Peraturan Presiden Nomor 70 Tahun 2012 concerning Second Amendment to Peraturan Presiden Nomor 54 Tahun 2010 concerning Procurement of Government Goods/Services) mandating the establishment of permanent ULP permanent which can stand alone or attached to an existing unit.

ULP is a unit that has fucntions to carry out the procurement of goods/services in the Ministry/ Institution/Regional Work Unit and other institutions that are permanent; ULP can stand alone or be attached to an existing unit. Article 14 Peraturan Presiden Nomor 54 Tahun 2010 stated that K/L/D/I are required to have ULP which can provide service/ training in the field of goods/service procurement. Article 130 stated that the $\mathrm{ULP}$ in $\mathrm{K} / \mathrm{L} / \mathrm{D} / \mathrm{I}$ (including the Ministry of National Development Planning/Board of National Development - hereafter will be referred to Kementrian PPN/ Bappenas) must already be formed and be functioned in the 2014 fiscal year. This means that the ideas and preparations for the formation of ULP must begin before 2014. The need for ULP is not merely about statutory obligations that have to be fulfilled, but it is about an urgent need which has to be formed immediately. Based on the participant's suggestion in the workshop held by Legal Bureau on February 8th, 2012, there were various problems found in the process showing that it is important to form ULP immediately.

West Java Provincial Government becomes one of the pilot projects for the development of Electronic Procurement Services (Lembaga Pengadaan Secara Elektronik, hereafter will be referred to LPSE) developed by Kementrian PPN/Bappenas c.q Center for the Development of Goods/Services Procurement Policy. The development of LPSE is also getting along with the formation of ULP set by Peraturan Gubernur Jawa Barat Nomor 36 Tahun 2008 as amended by
Peraturan Gubernur Jawa Barat Nomor 36 Tahun 2008. The ULP was formed in order to fulfill the provisions stipulated in the Keputusan Presiden Nomor 80 Tahun 2003 concerning Procurement of Government Goods/ Services along with their amendments.

The ULP in West Java Provincial Government is a non-structural unit which is attached and under the coordination of Regional Bureau of Goods Management. Its Head is -ex-officio held by Head of Regional Goods Management Bureau. Its secretary is ex-officio held by Section Head of Procurement and Distribution which is also in charge of Procurement and Distribution Section. Although it is ex-officio held, the job description of Head of Regional Goods Management Bureau and Section Head of Procurement and Distribution in the Governor Regulation concerning the Organizational Structure of Regional Apparatus put out the function of goods/services procurement.

Work relations are strictly stated in Peraturan Daerah Provinsi Jawa Barat No. 1 Tahun 2011 concerning the Organization and Secretariat Work Procedure of Committee of Indonesia Civil Servants Corps, West Java. It states that the work relation between ULP and regional organization is coordinatively related, and so is between ULP and work unit which have full independency in selecting the providers of goods/ services. Based on the findings carried out by Rodrigues, et. al. (2015), cooperation implication between public and private sector is really helpful in making decision for stakeholders in term of concept and research process.

Based on Rencana Tata Ruang Wilayah Provinsi (RTRWP) Jawa Barat 2009-2029, the North West Java is one of the areas which is included to the four of Development Areas, called Purwasuka Development Area. The leading sectors in this area are agriculture, plantation, animal husbandry, fisheries, marine business, processing industry, tourism and mining. Subang District is recently popular with its Patimban Port. Due to the change of this place, it will attract investors to invest and there will be many studies and works carried out. The condition will require ULP performance which satisfies SKPD and Partners.

The most recent issues stated that ULP tends to be allegedly not neutral in caarying the process of selecting goods/services providers. Therefore, SKPD often found themselves dissatisfied because ULP has a prospective supplier of goods/services to be won at the auction process. ULP is suspected of being inaccurate in conducting evaluations therefore the providers set as winners are not able to carry out the program. ULP allegedly: (1) makes the registration process of procurement packages complicated by making ample requirements; (2) buys some time in the procurement process by looking for errors in the documents so that the project implementation in the field will not be completed on time; (3) does not conduct the bidding procedures properly and correctly, therefore it is prone to cause 
other problems in the future. From the prospective of goods/services suppliers, the ULP is suspected to: (1) have other prospective of goods/services suppliers to be selected as the winner; (2) be inconsistent in carrying out the bidding evaluation so that it tends to harm the prospective supplier; (3) takes side on the prospective supplier so that it is deemed to impose them to be the winner; (4) does not carry out the bidding procdures which have been stated in the Presidential Regulation properly and correctly.

Hadiyati (2014) stated that government through agencies, departments, and ministries provides information and services for each customer group and as a result, the customers give their assessment to the performance delivered. In accordance to people's needs service demands keep changing as the globalisation grows. People's demands are strongly dependent on the level of needs and the individual and social value. This, therefore, enforce the apparatus to role more positively in assisting people to fulfil their needs.

The research carried out by Rizq, et. al. (2018) related to employees' performance satisfaction in the Department of Population and Civil Registration stated that public or customers have already been satisfied with the employees' performance. However, there are also dissatisfaction from the customers towards the employees' performance because it has not been able to meet the expectations of the community, namely in terms of ease of handling requirements, speed of service processes and facilities.

Rhee and Rha (2009) stated that four main qualities of public service are identified: process quality, outcome quality, design quality, and relationship quality. The findings suggest that the critical attributes of public service quality for customer satisfaction differ according to the types of customers in the public sector. Final customers (beneficiaries) give priority to the process and outcome qualities, whereas intermediary customers (social workers) have high regard for the design and relationship qualities.

Based on these issues and refutation, it is important to carry out a research which relates to the level of satisfaction based on the fact experienced by SKPD and Partners as well, related to the service provided by Government ULP of Subang District. The satisfaction has close relation to the service quality measured by tangible, empathy, responsiveness, reliability, and assurance. The better the quality of services provided, the higher the level of satisfaction felt by service users. Some improvements should be carried out in the Government ULP of Subang District, including by conducting few researches to find out the customers' satisfaction - which is, in this case, SKPD and Partners - towards the service provide and the most important element as evaluation as well. These should be further carried out in order to provide better, more effective and more efficient service.
Quality and satisfaction are distinctly defined though obviously related. Perceived quality is a form of attitude, and results from comparing expectations with perceptions of performance. Define a set of gaps occurring at different stages of the service design and provision, which altogether result into the ultimately relevant gap between consumers' expectations prior to the service delivery and consumer perceptions during the service delivery. This gap was first defined for 11 dimensions or domains of the service provision (access, competence, responsiveness, reliability, courtesy, communication, credibility, security, understanding and knowing the customers, and tangible), which were later reduced to five (responsiveness, reliability, assurance, empathy and tangible) Parasuraman et. al. (1988).

Titua and Vlad (2014) stated in their research that to show evidence in term of quality measure through quantification of the current level of performance from an organization, such as local public administration, should be based on the performance standard. Quality evaluation measures the difference between the expected performance and actual performance. It is done in order to identify and improve public quality. Performance standard can be set for different dimension of quality, such as for management quality of document, product, process and service which require the collection and analysis of information specified in term of measurement.

Azizzadeh, et. al. (2013) stated that providing a good service and normal price in the professional level will lead both organization and business to a consistent competitive excellence, which will also create and provide unique service, improve customers' loyality, decrease marketing cost, determine higher proper price and others. The life sustainability of organization and profitability depends on the improvement of customers' satisfaction therefore the service quality should be continuously evaluated from their point of view. Chatzoglou, et. al. (2013) explained that no matter how great an institution, both public and private, if it is not supported by people who care, they will still dissatisfy. Therefore, citizens must actively participate in the process of service planning and provision.

\section{METHODS}

This research is descriptive and verificative by using descriptive method and explanatory survey. The analysis units are SKPD and Partners in Subang District. This research is cross-sectional, an information of the sample obtained when collecting information about the objects being researched which are service quality and customers' satisfaction: SKPD and Partners. Samples being taken were about 133 persons, containing 24 Commitment-making Official while the rest of it are partners set randomly about 109 persons. The data in this research is managed by using path analysis. Service quality is measured by dimension of tangible, empathy, responsiveness, reliability, and assurance. 


\section{RESULTS}

Based on the research result by spreading 133 questionnaires to SKPD and partners, the data were tested for validity, realiability, and normality, which will be further processed. Based on the descriptive analysis result, the average score of each dimension of service quality are obtained and explained as Table 1.

Tangible is a dimension which forms service quality. It is divided into 3 indicators of question, including about cleanliness, facility and infrastructure and employees' neatness. Based on the descriptive analysis result of respondent's response on service quality of tangible dimension with 3 questions, it has an average score of 3.544 and is categorized as good. It indicates that physical evidence given from ULP to SKPD and Partners is considered relatively good, although there are still some which are inoptimal. Its cleanliness has the highest average score compared to its facilities and infrastructure. This is because there are several facilities that cannot be used optimally by SKPD and Partners even though they already exist. Therefore, they have not already used these facilities for making auction/ bidding process in ULP.

Empathy is a dimension which forms service quality. It is divided into 4 indicators of question, including about kindness, caring, emotional control and ease of consultation. Based on the descriptive analysis result of respondent's response on service quality of empathy dimension with 4 statements, it has an average score of 3.628 and is categorized as good. It indicates that the empathy given from ULP to SKPD and Partners is considered relatively good, although there are still some which are inoptimal. Staff of ULP has highest average score on their kindness compared to the ease consultation. It indicates that ULP do care about the auction/bidding process. Because there are a lot more people participating at the bidding/auction, there will be also a better company because of strict selection. However, ULP has to keep their commitment on all participants. Excessive consultation will cause a biased professionalism between ULP employees, because there is assumption that ULP is taking sides on one of the bidders/auctioneers.

Reliability is a dimension which forms service quality. It is divided into 2 indicators of question, including about auction material and the use of IT (Information and Technology) in conducting the auctions. Based on the descriptive analysis result of respondent's response on service quality of reliability dimension with 2 statements, it has an average score of 3.575 and is categorized as good. It indicates that the reliability of ULP staff is considered relatively good, although there are still some which are inoptimal. ULP staff has mastered the auction material pretty well, while has not been really good in using the IT. It is because the technology used is not entirely functioning properly, so there are still those who use manuals for checking the auction files. Therefore, the staff actually has pretty good skill but they are not provided with proper facilities and infrastructure which is used inoptimally. However, ULP will still repair things related to the service quality.

Responsiveness is a dimension which forms service quality. It is divided into 3 indicators of question about speed of serving, speed of repairing and readiness of response. Based on the descriptive analysis result of respondent's response on service quality of responsiveness dimension with 3 questions, it has an average score of 3.446 and is categorized as good. It indicates that the responsiveness of ULP staff is considered relatively good, although there are still some which are inoptimal. They have pretty good speed in providing and fixing few requirements given by SKPD and Partners, but they lack in providing service. It signifies that with the lack of number of ULP staff, there are some participants of SKPD and Partners that are inoptimally served by the staff because there are many participants joined in the auction.

Assurance is a dimension which forms service quality. It is divided into 3 indicators of question about the ability of giving secure environment, agency's good reputation and ability of providing competent staffs. Based on the descriptive analysis result of respondent's response on service quality of assurance dimension with 3 questions, it has an average score of 3.649 and is categorized as good. It indicateds that the assurance given by relatively good, although there are still some which are inoptimal. The staff of ULP gives their assurance to SKPD and Partners if there is lack of data. The assurance will be automatically seen by SKPD and Partners, such as safe environment. However, there are also several staffs who should attend the training to improve their competence.

Based on Table 1, it describes the reponses of customers' satisfaction variable consisting 13 statements. It also stated that the average score of customers's satisfaction is 3.615 and categorized as good. It indicates that SKPD and Partners have already met their satisfaction with the service quality given by ULP. The highest average score lays on the condition of SKPD and Partners' willing to attend every meeting arranged by ULP, SKPD and Partners' closeness to ULP and SKPD and Partners' pleasure with the auction method set by ULP. However, in fact, there are still some things which need to be fixed by the staff of ULP; which include their willing to fulfill the requirement and their pleasure with the facility provided in ULP. Therefore, SKPD and Partners have basically met their satisfaction although there are still few things needed to be fixed. The need of SKPD and Partners has also basically been fulfilled by the staff's performance.

Research result obtained by using SPSS and Lisrel showed in Figure 1. Based on the calculation result of correlation value and path coeficient carried out 
by using SPSS 20.0, these are the following result of service quality towards customers' satisfaction, as seen in the Table 2.

The number of both direct and indirect influence of tangible, empathy, reliability, responsiveness and assurance dimension on customers' satisfaction. Based on Table 2, the influence of tangible, empathy, reliability, responsiveness, and assurance dimension on customers' satisfaction is $60.7 \%$. While the rest of them, about $39.3 \%$ is influenced by other variables outside the model which is not being researched.

Table 3 shown that the influence of service quality dimensions on customer satisfaction is influenced by direct and indirect effects. Direct effect of tangible dimension on customers' satisfaction is $2.13 \%$ while its indirect effect is $4.80 \%$ by four other dimensions: empathy $1.85 \%$, reliability $1.61 \%$, responsiveness $0.91 \%$ and assurance $0.43 \%$. The indirect effect of tangible dimension on customers' satisfaction gives higher influence compared to its direct effect. It indicates that tangible dimension is an influencial factor if there are other dimesions supporting to give influence on the customer. Therefore, the direct and indirect of tangible dimension on customers' satisfaction lays on $6.93 \%$.

Direct effect of empathy dimesion on customers' satisfaction is $9.12 \%$ while its indirect effect is $6.90 \%$ by four other dimensions: tangible $1.85 \%$, reliability $2.27 \%$, responsiveness $1.24 \%$ and assurance $1.54 \%$. The direct effect of empathy on customers' satisfaction gives higher influence compared to its indirect effet. It indicates that empathy dimension is one of the dominant factors in improving customers' satisfaction. Therefore, the direct and indirect of empathy dimension on customers' satisfaction lays on $16.02 \%$

Direct effect of reliability dimension on customers' satisfaction is $11.16 \%$ while its indirect effect is $7.82 \%$ by four other dimensions: tangible $1.61 \%$, empathy $2.27 \%$, responsiveness $1.90 \%$, and assurance $2.04 \%$. The direct effect of reliability on customers' satisfaction gives higher influence compared to its indirect effect. It indicates that reliability dimension is one of the dominant factors in improving customers' satisfaction. Therefore, the direct and indirect effect of reliability dimension on customers' satisfaction lays on $18.98 \%$.

Direct effect of assurance dimension on customers' satisfaction is $5.20 \%$ while its indirect effect is $5.44 \%$ by four other dimensions: tangible $0.43 \%$, empathy $1.54 \%$, reliability $2.04 \%$ and responsiveness $1.44 \%$. The indirect effect of assurance dimension on customers' satisfaction gives higher influence compared to its direct effect. It indicates that assurance dimension is an influencial factor if there are other dimesions supporting to give influence on the customer. Therefore, the direct and indirect of assurance dimension on customers' satisfaction lays on $10.64 \%$.

Based on the calculation, compared to the other dimensions, the highest partial or individual influence on customers' satisfaction is reliability dimension which lays on $18.98 \%$. It indicates that reliability has high influence which will also provide satisfaction for customers, who, in this case, SKPD and Partners. Therefore, ULP needs to always improve their staffs' competence in providing optimal service to the third party. Other than service quality explained above, there are many variables giving influences on customers' satisfaction. It is shown and based on the effect outside the model for $39.3 \%$, such as communication, commitment, etc.

\section{DISCUSSION}

Service quality is an expected level of excellence and management of level of excellence to fulfill customers' expectation (Lovelock translated by Widyantoro, 2000). In improving the quality, a company should pay attention and improve the commitment, awareness and ability of employees and staff as well, especially for those who involve directly with the customers. Although the quality system and technique are mostly correct but there are incorrect ways to implement the tools, an optimal quality should be only an expectation. A level of service quality depends on how customers responds to the real service based on what they expected to be in their mind. In the other words, service quality is a difference between customers' expectation/desire and their perceptions.

Measuring the service quality requires the understanding of dimension of service quality itself. There are many researches about factors which effect to the service quality. There are also many researches carried out by experts in the field of Service Management to find out the detail of the dimension of service quality influencing its service, including in finding out the most determining dimension in certain service quality.

A continuous improvement cannot be accomplished without quality measurement. It is done to find out the service quality provided and find out whether it is useful for the management and employees in seeing their perceptions about quality and realizing how far they really understand about customers' perceptions. This needs to be done in order to anticipate the gap between them.

Peraturan Menteri Pendayagunaan Aparatur Negara dan Reformasi Birokrasi No. 63/ 2003 concerning General Guidelines for Public Service Implementation stated that the essence of public service is the provision of excellent service to the community which is a manifestation of the responsibilities of government officials as public servants. This statement strengthens the role of the government as an agency that provides excellent service to the community. It is basically because customers/communities are citizens whose rights must be fulfilled. This includes the government, as an agency that provides services, 
must be able to provide the best possible service in accordance with laws and regulations.

Based on the average score of service quality about 3.57, it showed that the quality of ULP was still categorized as sufficience. Therefore, SKPD and Partners, as respondent, assessed the service quality provided by ULP quite good because ULP gave an excellent service to them. The cleanliness of physical facilities was specifically assessed because they would be a comfortable area for SKPD and Partners to wait if there are something that needs to be fixed, such as the lack of auction data or useful information for SKPD and Partners.

Nevertheless, ULP still needs to improve few things, such as their responsiveness. It is seen by the fact that ULP staffs are not quite responsive serving SKPD and Partners. It was also because there were several thick auction files which require accuracy for the staffs to read and check. There were some staffs who could not handle the complaints from SKPD and Partners because of their load of works.

Customers' satisfaction arises based on customers' response to the products they have used, by comparing what they feel after buying to what they have expected before. The satisfaction plays an important role in these competed industries because there are huge differences between the satisfied and very-satisfied customers.

A less-satisfied/neutral customer will move to others competitor, while a very-satisfied customer will also be loyal even if there is an interesting offer from the competitor. The feeling of satisfaction itself will lead the customers to buy and reconsume the product, while dissatisfaction will disappoint the customers and stop them to come and buy the product.

The implication of customers' satisfaction measurement is that the customers are involved in improving the product and service by indentifying what are needed by customers and building up emotional good relation with the customers in order to make them feel comfortable. It is different with the customers in the traditional concept, where they are not involved in developing the product because they are outside the system.

The purpose of involving the customers in developing the product and service is to make the company be able to fulfill customers' expectation, even if it is possible - beyond their expectation. An accurate perception about customers' expectation is a necessary thing, but quite enough to provide satisfaction to the customers. The company should actualize their expectation to the design and standard of satisfaction. These design and standard of customers' satisfaction would further be developed based on customers' expectation and priority.

Based on the descriptive analysis result, it showed that the average of customers' satisfaction is 3.615 which indicated that the satisfaction of SKP and Partners towards ULP performance was pretty good.
It also indicated that ULP has provided satisfaction for SKPD and Partners. ULP always gave comfort feeling for SKPD and Partners, both in their service and the auction method carried out by ULP staff. Therefore, basically, ULP has provided good service although there were few things that needed to be fixed, such as the facilities which could not be used properly by SKPD and Partners. It was because ULP was already fixing their system so that in the future, there will be no more disadvantages felt by SKPD and Partners by the current auction system.

Based on the calculation, compared to the other dimensions, the highest partial or individual influence on customers' satisfaction is reliability dimension which lays on $18.98 \%$. It indicates that reliability has high influence which will also provide satisfaction for customers, who, in this case, SKPD and Partners. Therefore, ULP needs to always improve their staffs' competence in providing optimal service to the third party. Other than service quality explained above, there are many variables giving influences on customers' satisfaction. It is shown and based on the effect outside the model for $39.3 \%$, such as communication, commitment, etc.

Based on the result above, in line with the research carried out by Parasuraman, et. al. (1988) and Tjiptono (2008) who stated that service quality measured by five dimensions gave effect to the customers' perception on satisfaction. At the same time, this aspect was also one of the sources that effect the customers' expectation. With the good quality of service, customers would also expect higher on their satisfaction. Therefore, it is important for the company to find out the most appropriate physical form of aspect. It is done to make a positive impression on the service quality for fulfilling customers' need and make them satisfied, but did not create a too-high expectation for them as well. Other than that, it is also in line with the research carried out by Widyastuti (2015) who stated that variable compliance, assurance, tangibles, reliability, responsiveness, empathy have given positive and significant effect on customers' satisfaction.

These results are also in line with the research of Caemmerer and Dewar (2013) who stated that nevertheless, this study makes several important contributions to the debate in the extant literature. First, it provides an insight into how levels of service quality compare between the private and the public sector from the recipients' perspective. For example, the results suggest that levels of expectations towards and perceptions of private and public services are similar. This contradicts the traditional notion that the quality of public services is inferior to those of the private sector. It is important to understand why this is the case. One explanation could be that, overall, public service provision has improved. The alternative explanation is that private sector services have been deteriorating. Obviously, the two are not mutually exclusive. But, 
regardless of the direction of this development, it is important from a marketing perspective to gain a better insight into if and how customers' perceptions of private sector services influence their expectations and perceptions as citizens towards public sector services, and vice versa. This will help to identify and implement appropriate marketing strategies to enhance service performance in individual sectors and industries by taking service quality in other sectors into account.

Nidhi and Kumari (2016) stated that the economic condition in India is a combination of public and private sectors. Indian customers enjoy services from both sectors. By this condition, there were also discrimination in the customers' preference either from public or private sector. The result showed us poor service quality and poor customers' satisfaction from the public sector compared to the private ones.

This was also supported by the research of Rha (2012) showing that a quality relation does not directly affect the customers' satisfaction, but it can indirectly effect the satisfaction by service quality and design. The influence of relation and design quality on customers' satisfaction are much more solid than the its service quality.

The result carried out by Khan, et. al. (2015) stated that government-sector organization, namely agencies, are not considered efficient. The consumers complained about poor service provided by the organization. In the case of PHF, the result described different condition. The customers were seemingly satisfied because they trusted the government about the safety of their invested money. Ownership and documentation services are transparent and fast. The policy claimed to create an affordable and economic life for the general public and government employees.

Salim, et. al. (2018) explained that the quality dimensions, which are tangible, emphaty, reliability, responsiveness, and assurance give significant effect to the customers' satisfaction. The research carried out by Iyikal and Celebi. (2016) stated that dimension of reliability and assurance gave positive significant effect to the customers' satisfaction in the public sector. Other than that, the level of satisfaction from public sector is quite significantly effected on the word of positive, literally by words, person to person.

\section{CONCLUSIONS}

Based on the analysis result and discussion, we can conclude that dimension of service quality measured by five dimensions: tangible, empathy, reliability, responsiveness, and assurance is considered good. The highest average score is assurance and the lowest average score is responsiveness. The service quality has quite significant effect to customers' satisfaction. The better the ULP's service quality, the higher the SKPD and Partner's satisfaction. The highest effect is reliability and the lowest is tangible.

\section{REFERENCES}

Azizzadeh, F., Khalili, K. and Soltani, I., 2013. Service quality measurement in the public sector (Ilam province post office case studies). International Journal, 2(1), pp.114-121.

Caemmerer, B. and Dewar, A., 2013. A comparison of private and public sector performance. Journal of Applied Business Research (JABR), 29(5), pp.1451-1458.

Chatzoglou, P., Chatzoudes, D., Vraimaki, E. and Diamantidis, A., 2013. Service quality in the public sector: the case of the Citizen's Service Centers (CSCs) of Greece. International Journal of Productivity and Performance Management.

Hadiyati, E., 2014. Service quality and performance of public sector: Study on immigration office in Indonesia. International Journal of Marketing Studies, 6(6), p.104.

Iyikal, O.C. and Celebi, A., 2016. Investigating a quality of services in the public sector: evidence from northern Cyprus. Journal of Economic and Social Development, 3(2), p.1.

Keputusan Presiden Nomor 80 Tahun 2003 tentang Pengadaan Barang/Jasa Pemerintah beserta dengan perubahannya.

Khan, M.B., Batool, I., Scholar, M. and Hussain, S., 2015. Customer Satisfaction at Public Sector: A Case Study of Pakistan Housing Authority. Pakistan Journal of Social Sciences (PJSS), 35(2).

Lembaga Kebijakan Pengadaan Barang/Jasa Pemerintah, 2013. Kajian Akademis Unit Layanan Pengadaan (ULP).

Lovelock, C. H. 1999. Manajemen Pemasaran Jasa. Alih bahasa Agus Widiyantoro. 2000. PT. Indeks. Jakarta.

Nidhi and Krishna, K. 2016. Service Quality of Public Sector Organization in India. International Journal of Pure and Applied Management Sciences; Vol. 2016.1.2; pp. 15-21, ISSN: 2456-4516.

Parasuraman, A., Valarie A. Zeithaml, and Leonard L. Berry. 1988. Servqual: A Multiple-Item Scale for Measuring Consumer Perceptions of Service Quality, Journal of Retailing, 64 (Spring), 12-40.

Peraturan Daerah Provinsi Jawa Barat Nomor 1 Tahun 2011 Tentang Organisasi Dan Tata Kerja Sekretariat Dewan Pengurus Korps Pegawai Negeri Sipil Republik Indonesia Provinsi Jawa Barat.

Peraturan Gubernur Jawa Barat Nomor 36 Tahun 2008 jo. Nomor 45 Tahun 2008 tentang Unit Layanan Pengadaan Barang/Jasa Pemerintah Provinsi Jawa Barat.

Peraturan Menteri Pendayagunaan Aparatur Negara dan Reformasi Birokrasi No. 63/2003

Peraturan Menteri Pendayagunaan Aparatur Negara dan Reformasi Birokrasi Nomor 77 Tahun 2012.

Peraturan Presiden Nomor 54 Tahun 2010 tentang Pengadaan Barang/Jasa Pemerintah. 
Peraturan Presiden Nomor 70 Tahun 2012 tentang Perubahan Kedua atas Peraturan Presiden Nomor 54 Tahun 2010 tentang Pengadaan Barang/Jasa Pemerintah

Rencana Tata Ruang Wilayah Provinsi (RTRWP) Jawa Barat 2009-2029.

Rha, J.Y., 2012. Customer satisfaction and qualities in public service: an intermediary customer perspective. The Service Industries Journal, 32(12), pp.1883-1900.

Rizq, S., Djamaludin, M.D. and Nurhadryani, Y., 2018. Analysis of service quality satisfaction of e-ktp service at public administration and civil registration office of Bogor district. Journal of Consumer Sciences, 3(2), pp.55-65.

Rodrigues, E.P., Gomes, C.F. and Yasin, M.M., 2015. Toward education and training the human resources: meeting the challenge through a jointventure process approach between the public and private sectors. International Journal of Process Management and Benchmarking, 5(4), pp.387-407.

Table 1. Average Score of Service Quality Dimension

\begin{tabular}{lc}
\hline \multicolumn{1}{c}{ Dimension } & Average Score \\
\hline Tangible & 3.554 \\
Emphaty & 3.628 \\
Reliability & 3.575 \\
Responsiveness & 3.446 \\
Assurance & 3.649 \\
Average Score of Service Quality & 3.574 \\
Satisfaction & 3.615 \\
\hline
\end{tabular}

Salim, M., Samsul, B. and Muhammad, R.F., 2018. Customer Satisfaction (Public Satisfaction) On Services In Administrative Village Office. AsiaPacific Management and Business Application, 7(1), pp.17-30.

Rhee, S.K. and Rha, J.Y., 2009. Public service quality and customer satisfaction: exploring the attributes of service quality in the public sector. The service Industries journal, 29(11), pp.1491-1512.

Tjiptono, F., 2008. Service management mewujudkan layanan prima. Yogyakarta: Andi.

Titu, A.M. and Vlad, A.I., 2014. Quality Indicators in Reference to the Evaluation of the Quality Management of Services in Local Public Administration. Procedia Economics and Finance, 16, pp.131-140.

Widyastuti, N. 2015. Analisis Pengaruh Kualitas Pelayanan rerhadap Kepuasan Konsumen (Survei Padatamu Pelanggan yang Menginap di Harris \& Pop Hotels Denpasar). Jurnal Kajian Bisnis. Vol. 23, No. 2, 2015, $138-149$.

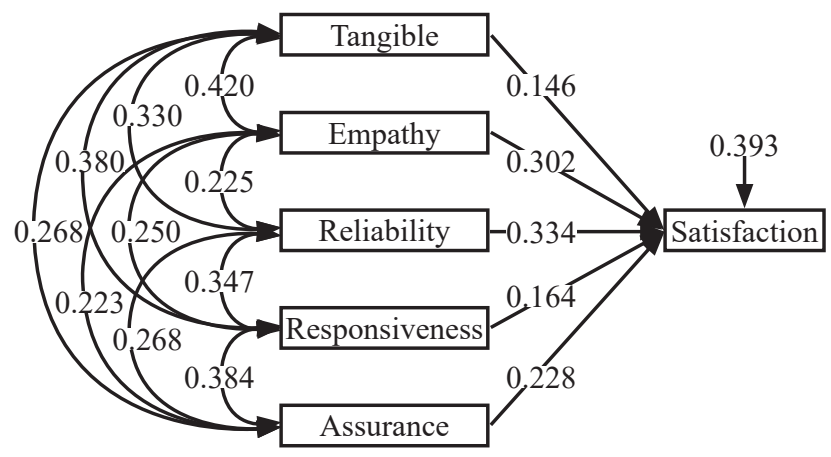

Figure 1. Effect of Service Quality Dimension on Satisfaction

Table 2. Test of Simultaneous Influence of Service Quality on Customers' Satisfaction

Model Summary

\begin{tabular}{cccccccccc}
\hline \multirow{2}{*}{ Model } & \multirow{2}{*}{$\mathrm{R}$} & \multirow{2}{*}{$\mathrm{R}$ Square } & \multirow{2}{*}{$\begin{array}{c}\text { Adjusted } \\
\text { R Square }\end{array}$} & $\begin{array}{c}\text { Std. Error of } \\
\text { the Estimate }\end{array}$ & \multicolumn{5}{c}{ Change Statistics } \\
\cline { 6 - 10 } & & & & R Square Change & F Change & df1 & df2 & Sig. F Change \\
\hline 1 & $.779 \mathrm{a}$ & .607 & .592 & 3.83154 & .607 & 39.284 & 5 & 127 & .000 \\
\hline
\end{tabular}

a. Predictors: (Constant), Assurance, Tangible, Reliability, Emphaty, Responsiveness

Table 3. Direct and Indirect Influence of Service Quality Dimension on Customers' Satisfaction

\begin{tabular}{lrrrrrrrr}
\hline \multirow{2}{*}{ Variable } & $\begin{array}{c}\text { Direct } \\
\text { Influence }\end{array}$ & \multicolumn{5}{c}{ Indirect Influence through } & $\begin{array}{c}\text { Total of Indirect } \\
\text { Influence }\end{array}$ & $\begin{array}{c}\text { Total of } \\
\text { Influence }\end{array}$ \\
\cline { 3 - 7 } Tangible & $2.13 \%$ & & $1.85 \%$ & $1.61 \%$ & $0.91 \%$ & $0.43 \%$ & $4.80 \%$ & $6.93 \%$ \\
Emphaty & $9.12 \%$ & $1.85 \%$ & & $2.27 \%$ & $1.24 \%$ & $1.54 \%$ & $6.90 \%$ & $16.02 \%$ \\
Reliability & $11.16 \%$ & $1.61 \%$ & $2.27 \%$ & & $1.90 \%$ & $2.04 \%$ & $7.82 \%$ & $18.98 \%$ \\
Responsiveness & $2.69 \%$ & $0.91 \%$ & $1.24 \%$ & $1.90 \%$ & & $1.44 \%$ & $5.48 \%$ & $8.17 \%$ \\
Assurance & $5.20 \%$ & $0.43 \%$ & $1.54 \%$ & $2.04 \%$ & $1.44 \%$ & & $5.44 \%$ & $10.64 \%$ \\
Total & $30.30 \%$ & $4.80 \%$ & $6.90 \%$ & $7.82 \%$ & $5.48 \%$ & $5.44 \%$ & $30.44 \%$ & $60.74 \%$ \\
\hline
\end{tabular}

